Journal of Economics and Behavioral Studies

Vol. 5, No. 8, pp. 496-504, Aug 2013 (ISSN: 2220-6140)

\title{
The Adoption of Internet Banking in a Developing Economy
}

\author{
*Jeevarathnam P Govender, Jun Wu \\ Durban University of Technology, South Africa \\ *govendej@dut.ac.za
}

\begin{abstract}
The international world has witnessed significant developments in internet banking. This has presented opportunities to both banks and customers in the world of e-commerce. The adoption rate for internet banking in South Africa has been low, compared to other developing countries. With a reasonably well developed infrastructure, South Africa presents itself with great market potential for internet banking. Given this scenario, this paper examines the factors influencing the adoption of internet banking in South Africa. A survey was conducted using a sample of 400 consumers using a quantitative and descriptive design. The results indicate a relationship between the selected biographical variables and the adoption of internet banking. Perceived usefulness, an indicator of relative advantage was associated with the adoption of internet banking. Users considered internet banking to be less complex and less costly than non-users. It emerged that both users and non-users did not consider social influences as being a factor in the adoption of internet banking.
\end{abstract}

Keywords: Internet banking, adopting of internet banking, internet banking in South Africa

\section{Introduction}

The past few decades have seen substantial innovations in the banking industry. This has been attributed to increased competition from current players, new entrants, increasing costs and the greater need by banks to satisfy a sophisticated consumer base. New technology has created more products, services and market opportunities. One of the major forces affecting business is technology, resulting in new products, market opportunities and more information orientated business management processes (Kazmi, 2011). Callaway (2011) believes that the internet has significantly affected all industries, transforming the way in which business is transacted. Thus, it has become necessary for banks to reconsider their marketing strategies. Apart from physical branches, banks need to offer alternative means of access to services, including via the internet (Zhao, Hanmer-Lloyd, Ward \& Goode, 2008). The context of this study is South Africa, a developing economy. It is envisaged that this paper bears relevance and has applicability to other developing economies. Sriram and Krishnan (2003) believe that information technology and the internet have had a profound impact on the financial services sector, as organisations in the industry are relying on information technology as an immediate source of competitive advantage. According to Gopalakrishnan, Wischnevsky \& Damanpour (2003), banks are at the forefront of pioneering the adoption of information technology and are actively pursuing their internet business.

The market for internet banking in developing countries is forecast to increase significantly in the next few years. Many consumers across the globe have adopted internet banking and a country like Pakistan, a developing economy, has shown a high adoption ratio (Kazmi, 2011). However, in 2003, 3.28 million people, a mere one in every fifteen South Africans had access to the internet. The estimate was 8.5 million people in 2012 , still a relatively low penetration rate at $17.4 \%$ compared to other countries in Africa such as Tunisia, with a penetration rate of $39.1 \%$ (Internet World Stats, 2012). This can also be viewed against the South African mobile telecommunications market, which exhibits a penetration rate of over $70 \%$ (South Africa Mobile Market Overview and Statistics Report, 2009). One of the obstacles facing South African consumers, when it comes to internet banking, is the high cost of bandwidth. The cost of internet usage in South Africa is over $475 \%$ more than in Egypt. One of the consequences is a significant slowdown in growth of internet users (Internet Growth in South Africa, 2012). South Africa, though, still remains a market with great potential for internet usage and internet banking with a per capita Gross National Income of US\$ 6100 (Internet World Stats, 2012). The primary objective of this paper is to analyse the factors influencing the adoption of internet 
banking in a developing economy, viz. South Africa. The subsidiary objectives are: to ascertain the demographic characteristics of users versus non-users of internet banking; to assess the perceptions of users versus non users regarding the relative advantages of internet banking; to assess the perceptions of users versus non users regarding the complexity of internet banking; to examine the perceptions of users versus non users regarding the perceived cost of internet banking and to assess the perceptions of users versus non users regarding the social influences on the adoption of internet banking.

\section{Literature Review}

Internet banking has been traced back to its origins in 1995, with the use of the internet as a remote channel for the delivery of banking services, allowing banks to offer informational as well as transactional services (Furst, Lang \& Nolie, 2002). Pyun, Scruggs \& Nam (2002) believe that internet technology has had a significant impact on the global financial industry, blurring the conventional boundaries that define product, market and customer. Technological advances such as the Internet have resulted in customers now having a variety of choices available regarding the type of service they want and the price they are prepared to pay. It is therefore essential that banks develop suitable Internet-related offerings, which identify with their customers and address their specific needs (Wang, 2008). Information technology is fundamentally changing the banking industry worldwide, altering traditional definitions of product, market and customer base. The growth of Internet banking has significantly affected barriers to entry and accelerated financial disintermediation (Pyun et al., 2007). Callaway (2011) believes that banks play a an essential role in financial intermediation as banks carry the risk of finding means of leveraging their liabilities and customer deposits, and to this end, the internet has facilitated this function. Gopalkrishnan et al. (2003) are of the opinion that that internet banking gives banks the opportunity to offer innovative products and secure new and different customers. According to Callaway (2011), through internet banking, a bank can expand its market reach. This is possible by being able to serve a larger geographic area with the need for additional brick and mortar branches. Customer congestion and waiting times at physical branches can be significantly reduced. The breadth of a bank's product line can be increased through internet banking. It is possible to offer a greater number of products per customer, as well as to customise products to specific customers. "One-stop shopping" would now be possible, creating opportunities for cross selling by encouraging customer traffic to a bank's website (Gopalakrishnan et al., 2003). Additionally, internet banking enables customers to consolidate their several financial services into a single website account (Pyun et al., 2002).

Consumers' acceptance of technological innovations such as internet banking may be influenced not only by their socioeconomic and demographic characteristics, but also by their attitudes towards specific technologies and by the characteristics of different products and services (Davis, 2009).An attitude is a learned tendency towards a product. Attitudes rest on an individual's value system, which represents personal standards of good and bad. The first approach by marketers is to turn neutral, negative or incorrect beliefs about product attributes into positive ones. Attitude motivates consumers towards a particular behaviour. It is therefore necessary for banks to instil a positive attitude among consumers, about internet banking as a product (McDaniel, Lamb \& Hair, 2012). Thus far, it would appear that financial service providers have failed to communicate a clear value proposition to customers. The findings of Goldstuck (2001) indicate that an issue-facing internet banking customers in South Africa is that they perceive the Internet, as a channel, as lacking functionality. Financial institutions thus face a challenge in demonstrating that using the Internet as a service channel is of benefit to the user and that functionality will be delivered. Lockett \& Littler (1997) found that a large proportion of consumers believed that twenty-four hour availability was the most important factor in their decision to use computer banking.

Interestingly, studies have found preference for face-to-face interaction in banking. Bank customers still like to opt for personal interaction when doing their bank transactions. The personal touch of officers and managers was perceived to add value to each transaction. This has been corroborated by research conducted by Suganthi, Balachander \& Balachandran (2001) who found, in the Malaysian context, that a personal relationship between customers and bankers transcends many boundaries especially so in the rural areas. About $90 \%$ of respondents valued human tellers very highly. Georgiades \& Dowsland (2000), in their studies, found that the lack of personal contact and face anonymity are seen as disadvantages to the extent that some websites have started to include photos and video clips of store owners and staff to overcome the perception 
that electronic storefronts are too impersonal. Gerrard \& Cunningham (2003) established that compatibility is a significant factor, which affects the adoption of internet banking. Banks have found significant cost reductions by moving customer accounts and support functions online. Such a move reduces the need for bank tellers and service consultants. It is estimated that in the USA, executing a typical service transaction at a bank costs over $\$ 1$ (Jones \& Hill, 2013). The same transaction conducted via telephone banking costs $\$ 0.54$, at an ATM, $\$ 0.27$ and over the internet, $\$ 0.02$ (Callaway, 2011). Internet banking, as much as having benefits, has its limitations. Kazmi (2011) indicates that hacking and identity theft pose major problem in that customers are not sure whether there is safety in their personal and account information. Although hackers, phishers and other criminals have been thwarted by banks, new channels, more sophisticated criminal mind, and the use of outsourcing pose new threats (Ginovsky, 2012). Compared to traditional banking, customers are not in a position go to a bank and express their problems face-to-face, and have a human response. Furthermore, if the internet service goes down, transacting is not possible (Calaway, 2011).

\section{Methodology}

The research constituted a quantitative, cross-sectional, and descriptive study. The key variables were demographics (gender, age, income, education level and occupation), and attitudes regarding internet banking with specific reference to relative advantage, complexity, perceived cost, and social influences. Attitude was measured using a five point Likert scale (strongly disagree-strongly agree). Respondents comprised a sample of 400 shoppers. Four major shopping Mallsin Durban, one of the major cities in South Africa, were chosen based on purposive sampling. At each shopping centre, 100 respondents were chosen using convenience sampling. The sample size was guided by Sekaran (2003) who suggests that for a population in excess of 1 million, a sample of 384 respondents is adequate to draw inferences.

\section{Results and Discussion}

As reflected in Table 1, it emerged that, of the 400 respondents, $80(20 \%)$ were users and $320(80 \%)$ were non-users of internet banking. $67 \%$ of users were male indicating that men are the predominant gender group using internet banking. This suggests that gender could be a factor that affects customer adoption of internet banking. The majority of the users (64\%) fell into the 30 to 39 age group. 53\% of non-users were in the 21-29 age categories. $84 \%$ of users were under 40 years of age, suggesting that internet users were generally young. The results indicate that the majority of users (50\%) earned between R6 000 and R7 999. The majority of non-users were in the low-income category (Less than R2 000). 66\% of non-users earned less than R4 000 per month. This finding concurs with those of Karjaluoto (2002), which indicate a strong relationship between income and the adoption of internet banking. It also emerged that internet banking users earned higher incomes than non-users. A comparison of the education levels of users and non-users as presented in Table 1 indicates that users were in possession of relatively higher qualifications, with 84\% having a tertiary qualification. Non-users, by comparison had lower educational qualifications. The higher education levels are particularly significant, as research by Polatoglu \& Ekin (2001) indicates that high levels of education enhance the consumer's ability to process information that is more complex and make decisions.

The occupation status of users and non-users indicates that the vast majority of users (94\%) were employed, with $81 \%$ being employed by someone or an organisation and $13 \%$ being self-employed (Table 1). Occupation status appears to have an influence on the use of internet banking. This corroborates with the research findings of Karjaluoto, Mattila \& Pento (2002) who found that internet banking customers were generally well educated, wealthy, and had good computing skills. Overall, the findings regarding demographic variables in this study concur with those of Laforet \& Li (2005) who found that demographic factors significantly affect on-line banking behaviour.

The relative advantages of internet banking: The following section reports on perceptions of internet banking specifically, the management of finances, time saving and communication with banks.

Internet banking enabling better management of finances: As indicated in Table 2, the majority of users believed that internet banking enables better management of finances, with $21.2 \%$ agreeing and $58.8 \%$ strongly agreeing that internet banking enabled them to manage their finances better. Non-users, on the 
other hand displayed a different attitude. $40 \%$ of non-users disagreed $(0.6 \%$ strongly disagreeing and $39.4 \%$ disagreeing) and $23.1 \%$ were neutral about internet banking enabling better management of their finances. This is supported by the mean value of 4.39 and 3.05 for users and non-users respectively.

Internet banking saving time: Interestingly, both users (100\%) as well as non-users (96.3\%) were in agreement about internet banking saving time. $3.7 \%$ of non-users were neutral as to whether they considered internet banking to be time saving. The mean scores of 4.8 and 4.46 confirm the overall extent of agreement.

Internet banking making communication with banks more comfortable: $75 \%$ of users agreed $(27.5 \%$ agreeing and $47.5 \%$ strongly agreeing) that internet banking made communication with banks more comfortable with a mean value of 4.2 . Non-users did not share the same view, with $38.1 \%$ of respondents disagreeing and $26.6 \%$ being neutral with regard to internet banking making communication with banks more comfortable. The mean score was 3.02 for non-users. These results are in keeping with the findings of Leaderer, Maupin, Sena \& Zhuang (2000), which suggest that perceived usefulness is associated with the adoption of electronic technologies.

Table 1: Biographical data

\begin{tabular}{|c|c|c|}
\hline Respondents $\quad n=400$ & Users (\%) & Non-Users (\%) \\
\hline \multicolumn{3}{|l|}{ Gender } \\
\hline Male & 67 & 48 \\
\hline \multirow[t]{2}{*}{ Female } & 33 & 52 \\
\hline & 100 & 100 \\
\hline \multicolumn{3}{|l|}{ Age } \\
\hline $21-29$ & 20 & 53 \\
\hline $30-39$ & 64 & 17 \\
\hline $40-49$ & 15 & 17 \\
\hline Over 50 & 1 & 13 \\
\hline Total & 100 & 100 \\
\hline \multicolumn{3}{|l|}{ Income (Rands) } \\
\hline Less than 2000 & 6 & 35 \\
\hline 2000-3999 & 10 & 31 \\
\hline 4000-5999 & 14 & 17 \\
\hline 6000-7999 & 50 & 8 \\
\hline 7999-9999 & 14 & 2 \\
\hline \multirow[t]{2}{*}{ Over 10000} & 6 & 7 \\
\hline & 100 & 100 \\
\hline \multicolumn{3}{|l|}{ Education level } \\
\hline Tertiary qualification & 84 & 34 \\
\hline Matriculation & 14 & 41 \\
\hline \multirow[t]{2}{*}{ Below matric } & 2 & 25 \\
\hline & 100 & 100 \\
\hline \multicolumn{3}{|l|}{ Occupation } \\
\hline Employed by someone/organisation & 81 & 42 \\
\hline Self employed & 13 & 9 \\
\hline Pensioner & 0 & 12 \\
\hline \multirow[t]{2}{*}{ Unemployed } & 6 & 37 \\
\hline & 100 & 100 \\
\hline
\end{tabular}

The complexity of internet banking: The following section reports on respondents' perceptions of conducting internet banking, complexity of using internet banking and the internet banking process.

The ease of conducting internet banking: As reflected in Table 3, 87.5\% of users agreed $(32.5 \%$ agreeing and 55\% strongly agreeing) about the ease of conducting internet banking. Non-users on the other hand, did 
not share the same viewpoint as users. $23.8 \%$ of non-users were in disagreement that internet banking was easy to use. The majority of non-users (55\%) were neutral in this regard.

Table 2: The relative advantages of internet banking

\begin{tabular}{|c|c|c|c|c|c|c|c|c|c|}
\hline & \multirow[t]{2}{*}{ The relative advantages of IB - Users } & & \multicolumn{5}{|c|}{$\begin{array}{c}1=\text { Strongly disagree } \\
5=\text { Strongly agree }\end{array}$} & \multirow[t]{2}{*}{ Total } & \multirow[t]{2}{*}{ Mean } \\
\hline & & & 1 & 2 & 3 & 4 & 5 & & \\
\hline \multirow{3}{*}{$\begin{array}{l}1 \\
2 \\
3\end{array}$} & IB enabling better management of finances & $\%$ & 0 & 0 & 20.0 & 21.2 & 58.8 & 100 & 4.39 \\
\hline & IB saving time & $\%$ & 0 & 0 & 0 & 8.2 & 91.8 & 100 & 4.80 \\
\hline & $\begin{array}{l}\text { IB making communication with banks more } \\
\text { comfortable }\end{array}$ & $\%$ & 0 & 2.5 & 22.5 & 27.5 & 47.5 & 100 & 4.20 \\
\hline \multirow{4}{*}{$\begin{array}{l}1 \\
2 \\
3\end{array}$} & The relative advantages of IB - Non-users & & & & & & & & \\
\hline & IB enabling better management of finances & $\%$ & 0.6 & 39.4 & 23.1 & 28.1 & 8.8 & 100 & 3.05 \\
\hline & IB saving time & $\%$ & 0 & 0 & 3.7 & 46.3 & 50.0 & 100 & 4.46 \\
\hline & $\begin{array}{l}\text { IB making communication with banks more } \\
\text { comfortable }\end{array}$ & $\%$ & 0.6 & 38.1 & 26.6 & 28.4 & 6.3 & 100 & 3.02 \\
\hline
\end{tabular}

Table 3: The complexity of Internet banking

\begin{tabular}{|c|c|c|c|c|c|c|c|c|c|}
\hline & & & & & disagı & $5=S t$ & igly & & \\
\hline & The complexity of IB - Users & & & & agre & & & Total & Mean \\
\hline & & & 1 & 2 & 3 & 4 & 5 & & \\
\hline 1 & The ease of conducting IB & $\%$ & 0 & 0 & 12.5 & 32.5 & 55.0 & 100 & 4.43 \\
\hline 2 & The complexity of using IB & $\%$ & 61.3 & 15.0 & 17.5 & 3.7 & 2.5 & 100 & 1.71 \\
\hline 3 & The simplicity of the IB process & $\%$ & 0 & 2.5 & 16.3 & 42.4 & 38.8 & 100 & 4.18 \\
\hline & The complexity of IB - Non-user & & & & & & & & \\
\hline 1 & The ease of conducting IB & $\%$ & 2.2 & 21.5 & 55.0 & 19.4 & 1.9 & 100 & 2.97 \\
\hline 2 & The complexity of using IB & $\%$ & 1.3 & 11.6 & 41.6 & 41.3 & 4.2 & 100 & 3.36 \\
\hline 3 & The simplicity of the IB process & $\%$ & 6.9 & 40.3 & 47.8 & 4.1 & 0.9 & 100 & 2.52 \\
\hline
\end{tabular}

The mean value for users and non-users was 4.43 and 2.97 respectively, indicating the extent of the difference in opinion between the two respondent groups regarding the ease of conducting internet banking.

The complexity of using internet banking: The results indicate that users did not consider internet banking to be complex, whereas non-users did. This is borne out in the mean value of 1.71 for users and for non-users, 3.36 as indicated in Table 3. 76.3\% of users disagreed (61.3\% strongly disagreeing and 15\% disagreeing) that internet banking was complex to use. On the other hand, $45.7 \%$ of non-users agreed that internet banking was complex to use, with 41.6 being neutral on the issue.

The simplicity of the internet banking process: The results, as reflected in Table 2, indicate significant differences in users' and non-users' perceptions of the simplicity of the internet banking process. The mean for users was 4.18 , compared to 2.52 for non-users. With regard to users, $42.5 \%$ agreed and $38.8 \%$ strongly agreed that the internet banking process was simple. $47.2 \%$ of non-users disagreed that the internet banking process was simple, with $47.8 \%$ being neutral on the issue. Clearly, users considered the internet banking process to be simple to a much greater degree than non-users. The results suggest that users considered internet banking to be complex to a smaller extent than non-users. This could explain the resistance to the adoption of internet banking by non-users. The results are consistent with the findings of Cheung, Chang \& Lai (2000) which indicate that ease of use has a positive influence on the adoption of internet banking. Internet providers have to make their offerings not only simple to use, but also simple to understand (Internet growth in South Africa, 2012).

The perceived cost of internet banking: Respondents' perceptions were ascertained regarding telecommunications costs, service costs, installation cost and cost effectiveness surrounding internet banking. 
Telecommunication costs are expensive: As reflected in Table 4,67.5\% of users were in disagreement (7.5\% strongly disagreeing and 60\% disagreeing) that telecommunication costs are expensive. Non-users on the other hand, did not share the same viewpoint as users. $69.7 \%$ of non-users agreed and $21.3 \%$ strongly agreed that telecommunication costs are expensive. The mean value for users and non-users was 2.65 and 4.11 respectively, indicating the extent of difference in opinion between the two respondent groups regarding telecommunication costs being expensive. This finding concurs with that of Botha (2002), that high Internet access costs is a factor, which inhibits row thin South Africa. Despite being open to competition, the South African internet sector faces an expensive operating environment created by Telkom, a fixed-line government controlled operator (South Africa Broadband and Internet Market Report, 2010). The results indicate that users did not consider internet banking service costs to be high as non-users did. This is borne out in the mean value of 2.67 for users and 4.18 for non-users as reflected in Table $4.66 .3 \%$ of users disagreed (7.5\% strongly disagreeing and $58.8 \%$ disagreeing) that internet banking service cost were high. On the other hand, $90 \%$ of non-users agreed (60.6\% agreeing and $29.4 \%$ strongly agreeing) that internet banking service costs were high. This view is supported by the Internet Society of South Africa, which has called for reduction in the cost of bandwidth to stimulate growth in internet usage (ISOC-ZA Trying to Lower Broadband Costs, 2004).

The cost of internet banking services: The results indicate that users did not consider internet banking service costs to be high as non-users did.

Table 4: The perceived cost of Internet banking

\begin{tabular}{|c|c|c|c|c|c|c|c|c|c|}
\hline & \multirow[t]{2}{*}{ The perceived cost of IB - Users } & & \multicolumn{5}{|c|}{$\begin{array}{c}\text { 1=Strongly disagree } \\
5=\text { Strongly agree }\end{array}$} & \multirow[t]{2}{*}{ Total } & \multirow[t]{2}{*}{ Mean } \\
\hline & & & 1 & 2 & 3 & 4 & 5 & & \\
\hline 1 & Telecommunications costs are expensive & $\%$ & 7.5 & 60.0 & 2.5 & 20.0 & 10.0 & 100 & 2.65 \\
\hline 2 & IB services costs & $\%$ & 7.5 & 58.8 & 2.5 & 22.5 & 8.8 & 100 & 2.67 \\
\hline 3 & The cost of internet installation & $\%$ & 6.3 & 56.3 & 3.8 & 22.5 & 11.3 & 100 & 2.76 \\
\hline \multirow[t]{2}{*}{4} & The cost-effectiveness of IB & $\%$ & 1.3 & 2.5 & 15.0 & 50.0 & 31.3 & 100 & 4.08 \\
\hline & The perceived cost of IB - Non-users & & & & & & & & \\
\hline 1 & Telecommunications costs are expensive & $\%$ & 0.6 & 0.3 & 8.1 & 69.7 & 21.3 & 100 & 4.11 \\
\hline 2 & IB services costs & $\%$ & 0.3 & 1.3 & 8.4 & 60.6 & 29.4 & 100 & 4.18 \\
\hline 3 & The cost of internet installation & $\%$ & 0.3 & 1.9 & 18.4 & 57.5 & 21.9 & 100 & 3.99 \\
\hline 4 & The cost-effectiveness of IB & $\%$ & 2.8 & 34.7 & 53.8 & 7.2 & 1.6 & 100 & 2.70 \\
\hline
\end{tabular}

This is borne out in the mean value of 2.67 for users and 4.18 for non-users as reflected in Table $4.66 .3 \%$ of users disagreed (7.5\% strongly disagreeing and 58.8\% disagreeing) that internet banking service cost were high. On the other hand, $90 \%$ of non-users agreed (60.6\% agreeing and $29.4 \%$ strongly agreeing) that internet banking service costs were high.

The cost of Internet installation: As reflected in Table 4, 62.6\% of users were in disagreement $(6.3 \%$ strongly disagreeing and $56.3 \%$ disagreeing) that the cost of internet installation is expensive. Non-users on the other hand, had somewhat the opposite view as users. $57.5 \%$ of non-users agreed and $21.9 \%$ strongly agreed that the cost of internet installation is expensive. The mean value for users and non-users viz.2.76 and 3.99 respectively further support this, indicating the difference in opinion between the two respondent groups regarding the cost of internet installation being expensive.

The cost-effectiveness of internet banking: The results, as reflected in Table 4, indicate significant differences in users' and non-users' perceptions regarding the cost-effectiveness of internet banking. The mean for users was 4.08, compared to 2.70 for non-users. With regard to users, 50\% agreed and 31.3\% strongly agreed that internet banking was cost-effective. $37.5 \%$ of non-users were in disagreement $(2.8 \%$ strongly disagreeing and $34.7 \%$ disagreeing) that internet banking was cost-effective, with $53.8 \%$ of nonusers being neutral on the issue. Clearly, users considered the internet banking process to be cost-effective greater degree than non-users. The findings therefore suggest that users perceived the costs associated with 
internet banking as being lower than non-users. Bareczal \& Ellen (1997) found that consumers will not adopt a new financial product unless it reduces cost and do not require them to change their behaviour when using it.

Social influences on internet banking: This section presents the findings on respondents' perceptions of the influence of friends, parents and colleagues on the adoption of internet banking.

The influence of friends on the use of internet banking: As reflected in Table 5, 48.8\% of users were in disagreement (46.3\% strongly disagreeing and $2.5 \%$ agreeing) that friends influenced the decision to adopt internet banking. The mean value of 2.56 indicates an inclination towards disagreement on this issue. Non users, with a mean value of 2.86, also displayed disagreement. Both users and non-users therefore did not view friends as being an influence on the adoption of internet banking. This is contrary to findings by Cheung, et. al. (2001) that classmates and friends are likely to have an influence on potential adopters and existing users of internet banking.

Table 5: Social influences on Internet banking

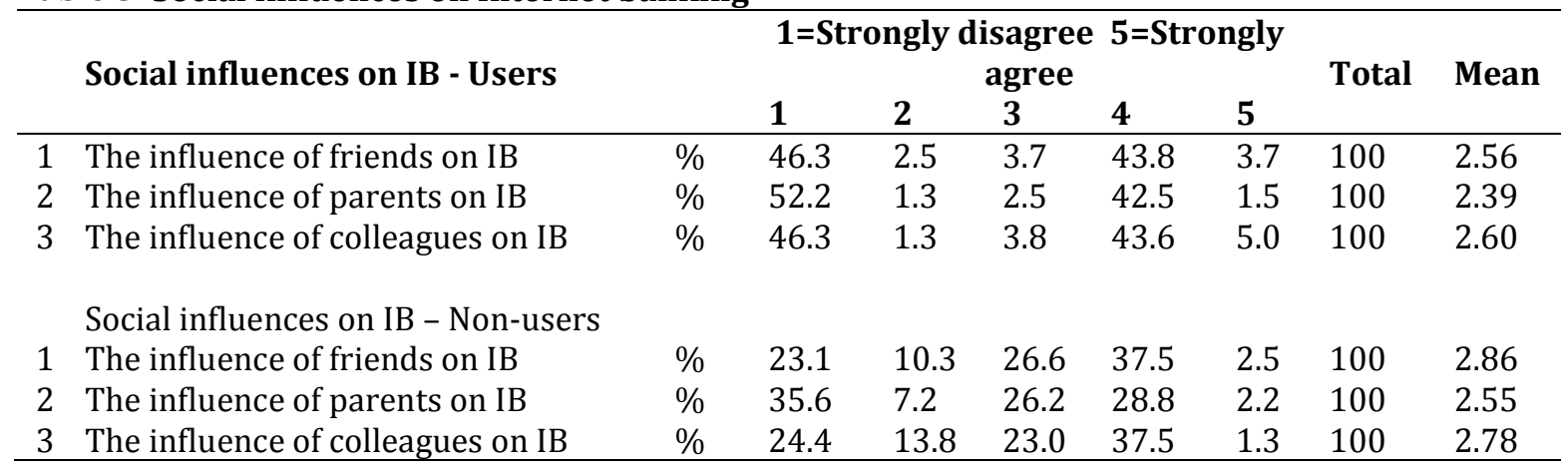

The influence of parents on the use of internet banking: As depicted in Table 5, both users and non-users had similar perceptions regarding the influence of parents on the adoption of internet banking. 53.5\% of users and $42.8 \%$ of non-users were in disagreement on the issue of parents influencing the adoption of internet banking. Interestingly, $26.3 \%$ of non-users were not sure about this. The mean value for users and non-users, viz. 2.39 and 2.55 respectively supports the view by users as well as non-users, that parents are not a strong influence on the adoption of internet banking.

The influence of colleagues on the use of internet banking: $47.6 \%$ of users were in disagreement (46.3\% strongly disagreeing and $1.3 \%$ agreeing) that colleagues influenced the decision to adopt internet banking. The mean value of 2.60 indicates an inclination towards disagreement on this issue. Non-users, with a mean value of 2.78 , also displayed disagreement. Although $38.2 \%$ of non-users were in disagreement, a further $23.1 \%$ were neutral about colleagues influencing the adoption of internet banking. Both users and non-users, therefore, did not view colleagues as being an influence on the adoption of internet banking. Interestingly, although the results indicate that social influences do not strongly influence the adoption of internet banking, McDaniel et al. (2012) believe that the internet plays a vital role in generating word-ofmouth communications, pointing out that more than $85 \%$ of the top 1000 US marketing firms have some form of word-of-mouth communications strategy.

Implications for practice: Banks should strive for maximum usage of their product offerings among current users, considering the relatively low cost of transacting via internet banking and that these customers are already on the bank's database. To this end, customers need to be made aware of the product range offered by the banks so that customers can maximise the use of such facilities. The appropriate marketing communication tools should be used in this regard. Non-users were generally not aware of the benefits of internet banking. Marketing communications should be used to convey the advantages of internet banking to this potential market. The relatively low cost of transacting using internet banking must be communicated to customers together with other value propositions. Many consumers are at the learning stage of internet banking. Helpful product information could prove useful in creating awareness among consumers with a 
view to developing confidence in using internet banking. Communicating relative advantages of internet banking is important. Banks thus face a challenge in demonstrating that using the Internet as a service channel will be worthwhile for the potential user and that functionality will be delivered. Banks should aim to make their internet banking as simple and easy to use as possible so that customers do not perceive them as being complicated or difficult to use.

\section{Conclusion}

This paper sought to examine the factors influencing the adoption of internet banking in South Africa, as a developing economy. The literature indicates substantial growth in internet banking in several economies, in both the developed the developing world, but a relatively low penetration rate in South Africa, despite having a well-developed infrastructure and a consumer base that has sufficient purchasing power. The results suggest a relationship between biographical variables and the adoption of internet banking. Perceived usefulness, an indicator of relative advantage was associated with the adoption of internet banking. Users considered internet banking to be less complex and less costly than non-users. It emerged that both users and non-users did not view friends, parents and colleagues as being social influences in the adoption of internet banking.

\section{References}

Bareczal, G. \& Ellen, P. (1997).Developing typologies of consumer motives for use of technologically-based banking services. Journal of Business Research, 38(2), 131-139.

Callaway, S. K. (2011). Internet banking and performance. American Journal of Business, 26(1), 12-25.

Cheung, W., Chang, M. K. \& Lai, V. S. (2000). Prediction of Internet and world web usage at work. Decision Success, 33(1), 45-57.

Davis, S. (1989). Perceived usefulness, perceived ease of use, and user acceptance of information technology. MIS Quarterly, 1(13), 319-339.

Furst, K., Lang, W. \& Nolie, D. (2002). Internet banking. Journal of Financial Services Research, 22(1/2), 95117.

Georgiaders, P. \& Dowsland, B. (2000). Attitude towards online purchase Behaviour. Working paper. European Business Management School.

Gerrard, P. \& Cunningham, J. B. (2003).The diffusion of internet banking among Singapore consumers. The International Journal of Bank Marketing, 21(3). Retrieved April 2, 2013 fromhttp://www.proquest.umi.com/pqdweb?index.

Ginovsky, J. (2012). New cyber threats and ways to meet them American Bankers Association. ABA Banking Journal, 104(1), 10-11.

Goldstuck, A. (2001). Internet access in South Africa. Retrieved March 15, 2013 from http://www.Itweb.co.za/sections/features/internet.

Gopalakrishnan, S., Wischnevsky, J. \& Damanpour, F. (2003). A multilevel analysis of factors influencing the adoption of internet banking. IEEE Transactions on Engineering Management, 50(4), 413-426.

Internet Growth in South Africa (2012). Retrieved April 5, 2013 from www.WildWorldWorx.

Internet World Stats. (2012). Internet Usage and Population Statistics. Retrieved March 15, 2013 from www.internetworldststs.com/af/za.htm.

ISOC-ZA Trying to Lower Broadband Costs. (2004). Retrieved March 5, 2013 from www.allAfrica.com.

Jones, G. R. \& Hill, C. W. L. (2013).Theory of Strategic Management. Mason, Ohio: South Western-Cengage Learning.

Karjaluoto, H. (2002). Electronic banking in Finland: Consumer Beliefs, Attitudes, Intentions and Behaviours. Journalof Financial Services Marketing, 6(4), 346-361

Karjaluoto, H., Mattila, M. \& Pento, T. (2002).Factors underlying attitude formation towards online banking in Finland. The International Journal of Bank Marketing, 20(2), 261-273

Kazmi, S. K.H. (2011). Internet Banking. Pakistan \& Gulf Economist, 30(21), 35-36.

Laforet, S. \& Li, X. (2005).Consumers' attitudes towards online and mobile banking in China. International Journal of Bank Marketing, 23(5), 362-380.

Leaderer, A. L., Maupin, D. J., Sena, M. P. \& Zhuang, Y. (2000).The technology acceptance model and the worldwide web. Decision Support Systems, 29(1), 269-282. 
Lockett, A. \& Littler, D. (1997). The adoption of direct banking services. Journal of Marketing Management, 13(2), 791-811.

McDaniel, C., Lamb, C. W. \& Hair, J. F. (2012).Marketing Essentials. Mason, Ohio: South Western-Cengage Learning.

Polatoglu, V. \& Ekin, S. (2001). An empirical investigation of the Turkish consumers' acceptance of Internet banking service. The International Journal of Bank Marketing, 19(4), 156-166.

Pyun, C., Scruggs, L. \& Nam, K. (2002). Internet banking in the US, Japan and Europe. Multinational Business Review, 10, 73-82.

Sekaran, U. (2003). Research Methods for Business: A Skill-Building Approach. New York: John Wiley.

Sriram, R. \& Krishnan, G. (2003). The value relevance of IT investments on firm value in the financial services sector. Information Management Resources Journal, 16(1), 46-62.

South Africa Broadband and Internet Market Report. (2010). Retrieved May 2, 2013 fromwww.internetworldststs.com/af/za.htm.

South Africa - Mobile Market Overview and Statistics Report. (2009). Retrieved April 3, 2013 from www.internetworldststs.com/af/za.htm.

Suganthi, L., Balachander, S. \& Balachandran, B. V. (2001). Internet banking Patronage: An investigation of Malaysia. Journal of Internet Banking and Commerce. Retrieved April 15, 2013 from http://www.arrraydev.com/commerce/jibc/010301.htm.

Wang, J. H. (2008). The function of Internet. Retrieved March 12, 2013 from http://www.scagri.gov.cn/b10025.txt. Accessed on 2005-03-11.

Zhao, A. L., Hanmer-Lloyd, S., Ward, P. \& Goode, M. H. M. (2008). Perceived risk and Chinese consumers' internet banking services adoption. The International Journal of Bank Marketing, 26(7), 505-525. 